\title{
Penerapan Enterprise Resource Planning (ERP) untuk Sistem Informasi Pembelian, Persediaan, dan Penjualan Barang pada Toko Emi Grosir dan Eceran
}

\author{
Ricky Akbar ${ }^{1}$, Juliastrioza ${ }^{2}$, Yolanda Rahmi Arici $^{3}$
}

\begin{abstract}
On Emi Store wholesale and retail business processes of purchasing, inventory, and sales are still made in the traditional and manual. This led to some problems, among others, is often an error occurred recording of purchases and sales of goods, calculation of the transaction, as well as the latest information the availability of goods in the warehouse. Therefore, it is necessary the implementation of Enterprise Resource Planning (ERP) system for purchase information, inventory, and sales of goods aimed at overcoming these problems. ERP implementation stage began with the study of introduction. Its activities namely the introduction of the company as a whole with interviews and observation, identifying the business processes of purchasing, inventory, and sales of goods that are currently running and then make a proposal system in terkomputerisasinya, which is described by using the Business Process Model Notation (BPMN), as well as the depiction of a working model of the system to be applied using use case diagrams. The next stage is to conduct a study of the literature of a variety of books and journals to find a foundation theory and related research. Then do the selection of ERP software, configuration and customization of the ERP software modules, as well as the last application and testing. The results of this study indicate that ERP software that have been selected and applied IE applications can address in Odoo Stores Emi wholesale and retail.
\end{abstract}

Intisari-Pada Toko Emi Grosir dan Eceran, proses bisnis pembelian, persediaan, dan penjualan barang masih dilakukan secara tradisional dan manual. Hal ini menyebabkan beberapa permasalahan antara lain, sering terjadi kesalahan pencatatan pembelian dan penjualan barang, perhitungan transaksi yang lama, serta lambatnya informasi ketersediaan barang di gudang. Oleh karena itu, perlu penerapan Enterprise Resource Planning (ERP) untuk sistem informasi pembelian, persediaan, dan penjualan barang yang bertujuan untuk mengatasi permasalahan tersebut. Tahapan penerapan ERP ini dimulai dengan studi pendahuluan. Aktivitasnya, pengenalan perusahaan secara utuh dengan wawancara dan observasi, mengidentifikasi proses bisnis pembelian, persediaan, dan penjualan barang yang sedang berjalan kemudian membuatkan usulan sistem secara terkomputerisasinya, yang digambarkan dengan menggunakan tools Business Process Model Notation (BPMN), serta penggambaran model kerja sistem yang akan diterapkan menggunakan use case diagram. Tahapan selanjutnya adalah melakukan studi literatur dari berbagai buku dan jurnal untuk mencari landasan teori dan penelitian terkait. Kemudian melakukan pemilihan perangkat lunak ERP, setelah itu melakukan konfigurasi dan kustomisasi modul perangkat lunak ERP tersebut, serta terakhir melakukan penerapan dan pengujian. Hasil penelitian ini menunjukkan bahwa perangkat lunak ERP yang telah dipilih dan diterapkan yaitu aplikasi Odoo

\footnotetext{
${ }^{1,2}$ Jurusan Sistem Informasi Fakultas Teknologi Informasi, Universitas Andalas, Kampus Universitas Andalas Limau Manis Padang - 25163 Indonesia

${ }^{3}$ Toko Emo Grosir dan Eceran, Kec. Koto Tangah Kota Padang

e-mail : juliaztrioza@gmail.com 1 , rickyakbar@fti.unand.ac.id ${ }^{2}$
}

dapat mengatasi permasalahan pada Toko Emi Grosir dan Eceran.

Kata Kunci : Enterprise Resource Planning (ERP), pembelian, persediaan, penjualan, aplikasi Odoo

\section{PENDAHULUAN}

Teknologi informasi telah menjadi unsur utama dalam strategi bersaing pada banyak dunia usaha. Integrasi teknologi di seluruh perusahaan memungkinkan pengguna informasi dalam perusahaan memiliki akses ke informasi yang dibutuhkan secara tepat waktu dan mengambil keputusan yang tepat[1]. Peran teknologi informasi saat ini tidak hanya dalam kegiatan operasional tetapi juga dalam kegiatan perencanaan dan pemberdayaan sumber daya lain dalam perusahaan. Teknologi informasi selalu terkait dengan penyediaan informasi, pengintegrasian sub sistem dan sistem serta pendukung manajemen yang baik. Penyelarasan antara proses bisnis dan teknologi informasi harus dapat dilakukan secara tepat agar semua sumber daya yang ada dapat optimal, dan teknologi informasi menjadi bagian yang tidak terpisahkan dari perusahaan[2].

Oleh karena itu, perlu pendekatan dalam pengembangan sistem yang terintegrasi di seluruh perusahaan. Saat ini, pendekatan yang populer untuk pengembangan sistem yang terintegrasi di seluruh perusahaan adalah penerapan sistem Enterprise Resource Planning (ERP). Sistem ERP adalah serangkaian aplikasi bisnis atau modul, yang menghubungkan berbagai unit bisnis dalam sebuah organisasi seperti keuangan, akuntansi, produksi, dan sumber daya manusia menjadi sebuah sistem tunggal yang terintegrasi secara kuat dengan platform umum untuk arus informasi di seluruh perusahaan[1].

Penerapan sistem ERP ke dalam perusahaan merupakan salah satu strategi yang banyak digunakan oleh perusahaan untuk meningkatkan kualitas sistem informasinya. Hal ini dikarenakan ERP merupakan bagian dari infrastruktur perusahaan yang dapat menunjang kelancaran proses bisnis perusahaan yang menerapkannya[3]. Saat ini terdapat dua jenis software ERP yang beredar di pasaran, yaitu proprietary software ERP dan open source software (OSS) ERP[4]. Kelebihan OSS ERP dibandingkan dengan proprietary software adalah mengurangi biaya, menurunkan tingkat ketergantungan perusahaan pada suatu vendor, dan meningkatkan adaptabilitas[5]. 
Toko Emi Grosir dan Eceran adalah sebuah perusahaan dagang yang berlokasi di pasar Simpang Tabing Kecamatan Koto Tangah, Kota Padang. Toko ini menjual berbagai macam kebutuhan sehari-hari yang dijual secara grosir dan eceran untuk produk-produk tertentu. Berdasarkan pengamatan penulis, produk yang dijual lebih kurang berjumlah 100 item seperti gula, kopi, roti tawar, teh, pasta gigi, sabun, deterjen (bahan pembersih), rokok, makanan ringan, minuman kemasan, kue kering, dan lain-lain. Setiap harinya, pelanggan yang datang lebih kurang 200 orang yang menyebabkan para staf kesulitan dalam melayani pembelian dari pelanggan. Kemudian, proses bisnis sehari-hari yang masih tradisional dan manual berdampak pada seringnya terjadi kesalahan pencatatan pembelian dan penjualan barang, proses perhitungan transaksi yang lama, sulit dalam pengelolaan barang, dan lambatnya informasi ketersediaan barang di gudang. Dengan diimplementasikannya ERP pada perusahaan ini dapat memberikan solusi atas permasalahan yang terjadi.

\section{LANDASAN TEORI}

\section{A. Pengertian ERP}

ERP adalah sistem informasi bagi perusahaan manufaktur maupun jasa, yang berperan mengintegrasikan dan mengotomasikan proses bisnis. Software ERP mendukung proses bisnis yang efisien dengan mengintegrasikan aktivitas bisnis, termasuk penjualan, pemasaran, produksi, logistik, akuntansi dan sumber daya manusia[6]

\section{B. Open Source Software (OSS) ERP}

Pada penelitian ini perangkat lunak ERP yang akan diterapkan adalah yang bersifat open source software (OSS). Adapun OSS ERP yang dipilih adalah Compiere, Openbravo, dan Odoo. Alasan pemilihan ketiga perangkat lunak ERP tersebut karena Openbravo dan Odoo merupakan dua dari tiga perangkat lunak yang paling sering digunakan di berbagai industry[7]. Sedangkan Compiere dan Openbravo merupakan perangkat lunak OSS ERP yang menduduki dua urutan teratas pada tahun 2009 (http://tech.gaeatimes.com) dan tahun 2010 (http://www.forecastingclouds.com). Berikut ini disajikan informasi ringkas tentang tiga OSS ERP tersebut.

1. Compiere : Compiere merupakan OSS ERP terintegrasi untuk solusi bisnis ERP dan CRM yang dibangun di atas Model Driven Application. Compiere menawarkan solusi bisnis dengan mengotomatiskan bagian keuangan, distribusi, penjualan, proses pelayanan, dan lainnya sehingga memberikan kemampuan pada industri maupun organisasi untuk dapat menjalankan bisnisnya secara cepat dan mudah.

.2. Openbravo : Openbravo merupakan software open source ERP berbasis web untuk perusahaan kecil dan menengah yang dirilis di bawah lisensi Openbravo Public, berdasarkan Mozilla Public License. Software ini dibangun di atas web based environment yang memiliki kemampuan untuk mengelola pengadaan, gudang, pengelolaan proyek dan pelayanan, produksi dan keuangan. Kustomisasi pada Openbravo dapat menghabiskan biaya tambahan, karena adanya kebutuhan untuk menambah atau mengostumisasi laporan statistic[7].

3. Odoo : Odoo (OpenERP) adalah sebuah perangkat lunak manajemen perusahaan berbasis open source. Aplikasi ini mampu melakukan seluruh otomatisasi perusahaan, meliputi sebagian besar kebutuhan dan proses perusahaan yang terintegrasi[8].

\section{Kegiatan Bisnis Perusahaan Dagang}

Pada perusahaan dagang, secara ringkas kegiatannya dimulai dari membeli barang dagangan, pengelolaan persediaan barang, dan menjual barang dagangan tersebut.

1. Pembelian Barang : Pembelian merupakan salah satu fungsi yang penting dalam berhasilnya operasi suatu perusahaan. Fungsi ini dibebani tanggung jawab untuk mendapatkan kuantitas dan kualitas bahan-bahan yang tersedia pada waktu dibutuhkan dengan harga yang sesuai dengan harga yang berlaku[9].

2. Pengelolaan Persediaan Barang : Persediaan dapat diartikan sebagai barang-barang yang disimpan untuk digunakan atau dijual pada masa atau periode yang akan datang[10]. Untuk perusahaan dagang, persediaan dinamakan persediaan barang dagangan (hanya ada satu klasifikasi), di mana barang dagangan ini dimiliki oleh perusahaan dan sudah langsung dalam bentuk siap untuk dijual dalam kegiatan bisnis normal perusahaan sehari-hari.

3. Penjualan Barang : Penjualan adalah rangkaian transaksi penjualan barang atau jasa baik secara tunai maupun kredit. Penjualan merupakan proses berpindah suatu hak atas barang atau jasa untuk mendapatkan sumber daya lainnya, seperti kas atau janji untuk membayar atau piutang[11].

\section{ANALISIS PROSES BISNIS PERUSAHAAN}

\section{A. Identifikasi Proses Bisnis Perusahaan}

Identifikasi proses bisnis dilakukan dengan melakukan analisis terhadap proses bisnis dari aktivitas yang sedang berjalan. Identifikasi proses bisnis yang dilakukan adalah proses bisnis yang relevan dengan ruang lingkup penelitian ini yaitu lingkup pembelian, persediaan, dan penjualan barang.

1. Proses Bisnis Pembelian Barang yang Sedang Berjalan: Toko Emi Grosir dan Eceran melakukan pembelian barang kepada distributor atau penyuplai barang yang telah ditetapkan. Proses bisnis untuk pembelian yang sedang berlangsung, ditampilkan dengan BPMN seperti terlihat pada gambar 1. 


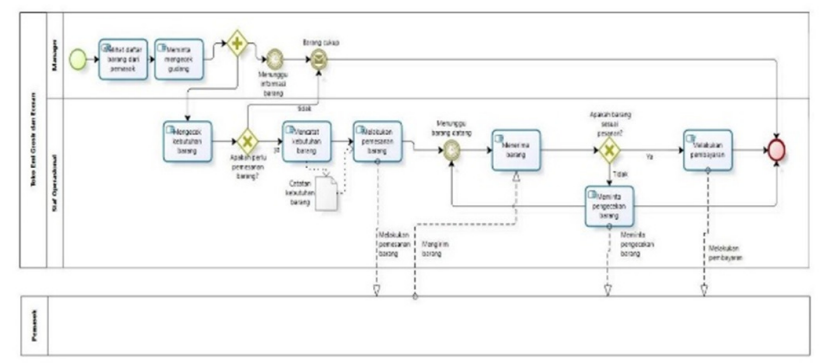

Gambar 1 BPMN proses bisnis pembelian barang yang sedang berjalan

2. Proses Bisnis Persediaan Barang yang sedang berjalan: Proses bisnis ini ditampilkan dengan BPMN seperti terlihat pada gambar 2.

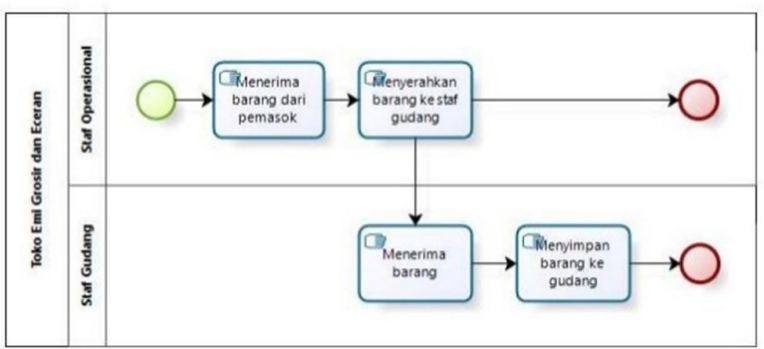

Gambar 2 BPMN persediaan barang yang sedang berjalan

3. Proses Bisnis Penjualan Barang yang sedang berjalan : Proses bisnis ini ditampilkan dengan BPMN seperti terlihat pada gambar 3.

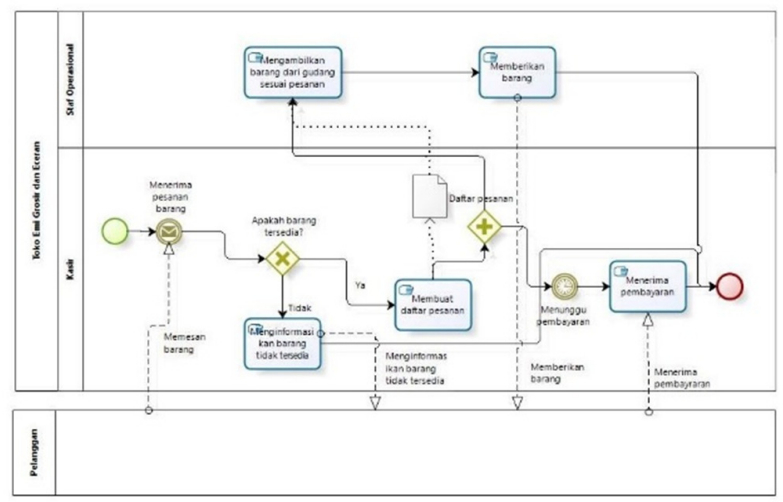

Gambar 3 BPMN proses bisnis penjualan barang yang sedang berjalan

\section{B. Sistem yang diusulkan}

Berikut ini diusulkan proses bisnis secara terkomputerisasi untuk Toko Emi Grosir dan Eceran yang meliputi proses bisnis pembelian, penyimpanan persediaan, pengecekan persediaan (stock opname) dan penjualan barang.

1. Proses Bisnis Pembelian Barang yang diusulkan : Proses bisnis ini ditampilkan dengan BPMN seperti terlihat pada gambar 4.

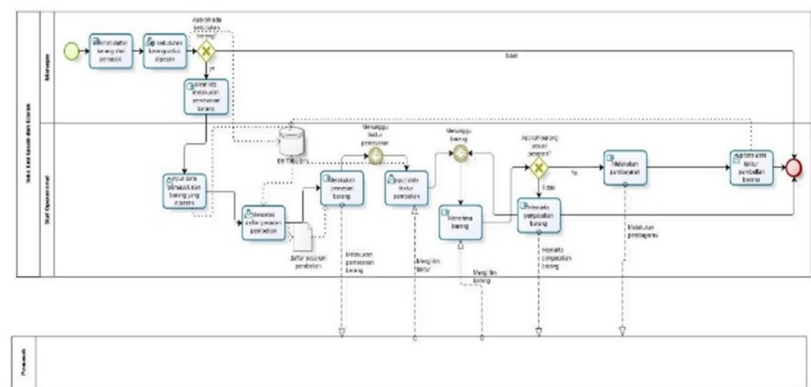

Gambar 4 BPMN proses bisnis penjualan barang yang diusulkan

2. Proses Bisnis Persediaan Barang yang diusulkan : Proses bisnis ini ditampilkan dengan BPMN seperti terlihat pada gambar 5 .

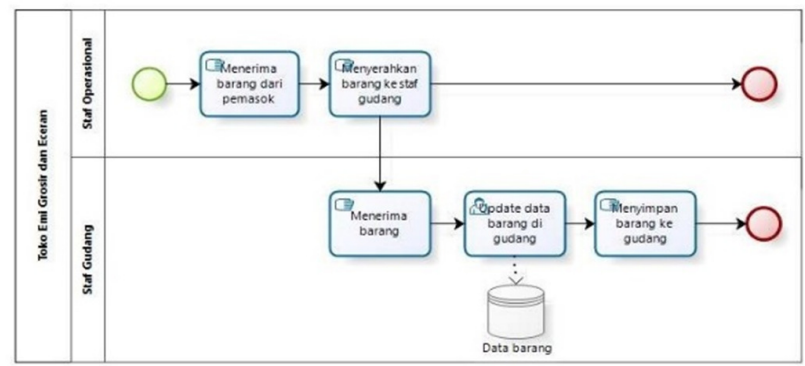

Gambar 5 BPMN Proses Bisnis Persediaan Barang yang Diusulkan

3. Proses Bisnis Pengecekan Stock Opname yang diusulkan : Proses bisnis ini ditampilkan dengan BPMN seperti terlihat pada gambar 6 .

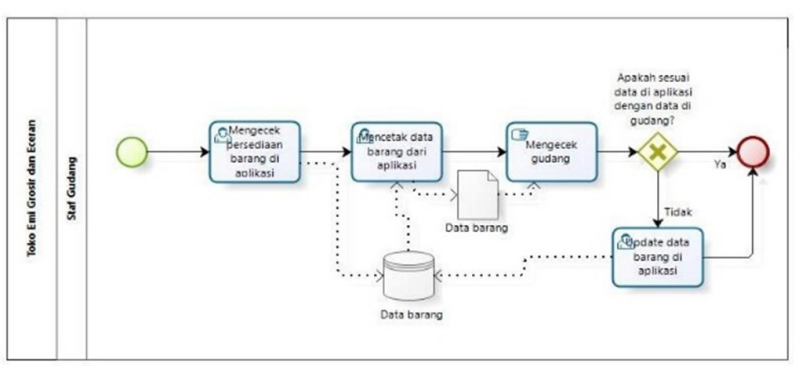

Gambar 6 BPMN Proses Bisnis Pengecekan Stock Opname yang Diusulkan

4. Proses Bisnis Penjualan yang diusulkan : Proses bisnis ini ditampilkan dengan BPMN seperti terlihat pada gambar 7 .

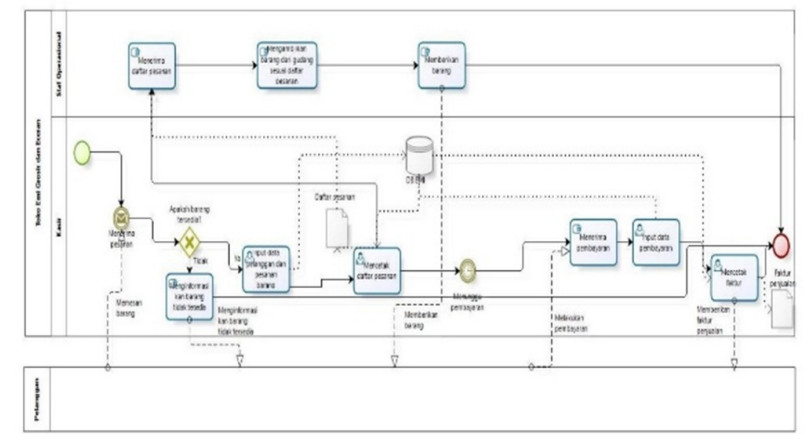

Gambar 7 BPMN proses bisnis penjualan yang diusulkan 


\section{Use Case Diagram}

Pada gambar 8 ditampilkan use case diagram untuk setiap aktor yang terlibat pada proses bisnis pembelian, pengelolaan persediaan, dan penjualan barang pada Toko Emi Grosir dan Eceran.

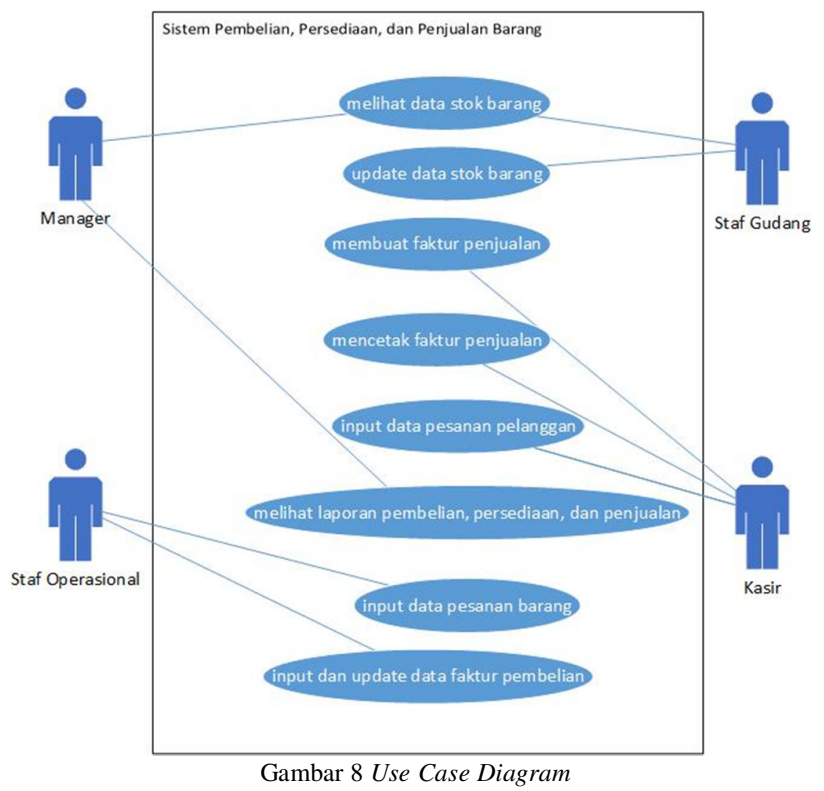

\section{ANALISIS PEMILIHAN OPEN SOURCE SOFTWARE ERP}

\section{A. Analisis Fitur Masing-masing OSS ERP}

Tahapan ini berguna untuk menganalisis fitur dari masingmasing perangkat lunak OSS ERP yang telah dijelaskan pada Bab 2 yakni Compiere, Openbravo, dan Odoo. Fitur-fitur tersebut mengacu pada best practice proses bisnis aplikasi ERP SAP untuk modul penjualan dan distribusi serta pengadaan barang. Dimana untuk modul penjualan dan distribusi barang proses bisnisnya best practicesnya adalah dimulai dari pre sales activity, sales order processing, manage inventory, shipping, customer invoice, dan customer payment. Sementara itu untuk proses pengadaan barang proses bisnisnya adalah purchase requisition, maintain quotation from vendors, purchase order, invoice receipt, dan payment to vendor.

Adapun yang menjadi acuan penelitian ini adalah penelitian dengan judul Analisis Fungsionalitas Open Source Software ERP untuk Pengembangan Modul Pembelajaran ERP oleh Putu Wuri Handayani dan Ultary Hariyaty (2011), yang membandingkan OSS ERP Compiere dan Openbravo yang mengacu pada fitur-fitur yang telah diidentifikasi, sedangkan untuk OSS ERP Odoo berdasarkan hasil pengamatan dan uji coba aplikasi yang penulis lakukan

1. Analisis untuk Proses Penjualan Barang : Berikut ini disajikan analisis fitur untuk masing-masing tahapan pada proses penjualan barang di aplikasi Odoo:

\section{Pre-sales Activity}

Pada proses pre-sales activity terdapat 22 fitur yang diamati. Berikut pemetaan kebutuhan fungsionalnya yang disajikan pada tabel 1 .

Tabel 1 Pemetaan Kebutuhan Fungsional Pre-Sales Activity

\begin{tabular}{|c|l|c|}
\hline No & \multicolumn{1}{|c|}{ Fitur } & Odoo \\
\hline 1 & Manage Customer Master & $\mathrm{V}$ \\
\hline 2 & Create Customer Master Data & $\mathrm{V}$ \\
\hline 3 & Update Customer Master Data & $\mathrm{V}$ \\
\hline 4 & View Customer Master Data & $\mathrm{V}$ \\
\hline 5 & Manage Material Master Data & $\mathrm{V}$ \\
\hline 6 & Create Material Master Data & $\mathrm{V}$ \\
\hline 7 & Update Material Master Data & $\mathrm{V}$ \\
\hline 8 & View Material Master Data & $\mathrm{V}$ \\
\hline 9 & Manage Pricing Master Data & $\mathrm{X}$ \\
\hline 10 & Create Pricing Master Data & $\mathrm{X}$ \\
\hline 11 & Update Pricing Master Data & $\mathrm{X}$ \\
\hline 12 & View Pricing Master Data & $\mathrm{X}$ \\
\hline 13 & Manage Inquiry & $\mathrm{X}$ \\
\hline 14 & Create Inquiry & $\mathrm{X}$ \\
\hline 15 & Update Inquiry & $\mathrm{X}$ \\
\hline 16 & View Inquiry & $\mathrm{X}$ \\
\hline 17 & Manage Quotation & $\mathrm{V}$ \\
\hline 18 & Create Quotation & $\mathrm{V}$ \\
\hline 19 & $\begin{array}{l}\text { Create Quotation without } \\
\text { Reference }\end{array}$ & $\mathrm{V}$ \\
\hline 20 & $\begin{array}{l}\text { Create Quotation with } \\
\text { Reference to Inquiry }\end{array}$ \\
\hline 21 & Update Quotation & $\mathrm{X}$ \\
\hline 22 & View Quotation & $\mathrm{V}$ \\
\hline & & \\
\hline
\end{tabular}

Berdasarkan tabel 1, aktivitas pre-sales activity untuk perangkat lunak Odoo dapat disimpulkan sangatlah efisien. Karena fitur-fitur yang dimilikinya adalah yang memang dibutuhkan untuk tahapan pre-sales activity. Sementara itu OSS ERP yang lainnya memiliki fitur yang sebenarnya tidak terlalu penting atau jarang digunakan seperti fitur manage pricing master data, create pricing master data, update pricing master data, view pricing master data, manage inquiry, create I nquiry, update inquiry, dan view inquiry.

\section{Sales Order Processing}

Pada proses sales order processing terdapat 7 fitur yang diamati. Berikut pemetaan kebutuhan fungsionalnya yang disajikan pada tabel 2.

Tabel 2 Pemetaan Kebutuhan Fungsional dari Sales Order Processing

\begin{tabular}{|c|l|c|}
\hline No & \multicolumn{1}{|c|}{ Fitur } & Odoo \\
\hline 1 & Manage Sales Order & V \\
\hline 2 & Create Sales Order & V \\
\hline 3 & $\begin{array}{l}\text { Create Sales Order without } \\
\text { Reference }\end{array}$ & V \\
\hline 4 & $\begin{array}{l}\text { Create Sales Order with } \\
\text { Reference to Quotation }\end{array}$ & $\mathrm{V}$ \\
\hline
\end{tabular}




\begin{tabular}{|c|l|c|}
\hline No & Fitur & Odoo \\
\hline 5 & Update Sales Order & V \\
\hline 6 & View Sales Order & V \\
\hline 7 & View Document Flow & $\mathrm{X}$ \\
\hline \multicolumn{2}{|c|}{ Total } & 6 \\
\hline
\end{tabular}

Dari tabel 2 disimpulkan bahwasanya Odoo merupakan perangkat lunak ERP open source yang sangat mumpuni dalam mengelola proses bisnis sales order processing. Ini dibuktikan dengan lengkapnya fitur yang dimilikinya, walaupun minus fitur view document flow yang terdapat pada Openbravo, namun fitur ini bukan merupakan fitur utama.

3. Manage Inventory

Pada proses manage inventory terdapat 2 fitur yang diamati. Berikut pemetaan kebutuhan fungsionalnya yang disajikan pada tabel 3 .

Tabel 3 Pemetaan Kebutuhan Fungsional Manage Inventory

\begin{tabular}{|c|l|c|}
\hline No & \multicolumn{1}{|c|}{ Fitur } & Odoo \\
\hline 1 & Manage Inventory & $\mathrm{V}$ \\
\hline 2 & $\begin{array}{l}\text { View Inventory } \\
\text { Availability }\end{array}$ & $\mathrm{V}$ \\
\hline \multicolumn{2}{|c|}{ Total } & 2 \\
\hline
\end{tabular}

Dari tabel 3 disimpulkan Odoo sangatlah baik dalam mengelola persediaan barang.

\section{Shipping}

Pada proses shipping terdapat 6 fitur yang diamati. Berikut pemetaan kebutuhan fungsionalnya yang disajikan pada tabel 4 .

Tabel 4 Pemetaan Kebutuhan Fungsional Shipping

\begin{tabular}{|c|l|c|}
\hline No & \multicolumn{1}{|c|}{ Fitur } & Odoo \\
\hline 1 & Manage Shipping & $\mathrm{V}$ \\
\hline 2 & $\begin{array}{l}\text { Create Outbond } \\
\text { Delivery with Reference } \\
\text { to Sales Order }\end{array}$ & $\mathrm{V}$ \\
\hline 3 & $\begin{array}{l}\text { Update Outbond } \\
\text { Delivery }\end{array}$ & $\mathrm{X}$ \\
\hline 4 & Pick Product & $\mathrm{V}$ \\
\hline 5 & Post Goods Issue & $\mathrm{X}$ \\
\hline 6 & View Outbond Delivery & $\mathrm{V}$ \\
\hline \multicolumn{2}{|c|}{ Total } & 4 \\
\hline
\end{tabular}

Dari tabel 4 dapat disimpulkan fitur yang dimiliki Odoo untuk proses bisnis shipping sangat efektif, sesuai dengan kebutuhan perusahaan.

\section{Customer Invoice}

Pada proses customer invoice terdapat 7 fitur yang diamati. Berikut pemetaan kebutuhan fungsionalnya yang disajikan pada tabel 5 .

Tabel 5 Pemetaan Kebutuhan Fungsional Customer Invoice

\begin{tabular}{|c|c|c|}
\hline No & Fitur & Odoo \\
\hline 1 & Maintain Billing Due & $\mathrm{X}$ \\
\hline
\end{tabular}

\begin{tabular}{|c|l|c|}
\hline No & \multicolumn{1}{|c|}{ Fitur } & Odoo \\
\hline & List & $\mathrm{X}$ \\
\hline 2 & View Billing Due List & $\mathrm{V}$ \\
\hline 3 & Create Invoice \\
\hline 4 & $\begin{array}{l}\text { Create Invoice with } \\
\text { Reference to Outbond } \\
\text { Delivery }\end{array}$ & $\mathrm{V}$ \\
\hline 5 & $\begin{array}{l}\text { Create Invoice with } \\
\text { Reference to Sales } \\
\text { Order }\end{array}$ & $\mathrm{V}$ \\
\hline 6 & Update Invoice & $\mathrm{V}$ \\
\hline 7 & View Invoice & 5 \\
\hline \multicolumn{2}{|c|}{ Total } \\
\hline
\end{tabular}

Dari tabel 5 dapat disimpulkan fitur Odoo untuk proses bisnis customer invoice sangat efisien dan efektif. Fitur-fitur yang bersifat opsional tidak dimiliki oleh aplikasi Odoo.

\section{Customer Payment}

Pada proses customer payment terdapat 3 fitur yang diamati. Berikut pemetaan kebutuhan fungsionalnya yang disajikan pada tabel 6 .

Tabel 6 Pemetaan Kebutuhan Fungsional Customer Payment

\begin{tabular}{|c|l|c|}
\hline No & \multicolumn{1}{|c|}{ Fitur } & Odoo \\
\hline 1 & $\begin{array}{l}\text { Manage Financial } \\
\text { Accounting }\end{array}$ & $\mathrm{V}$ \\
\hline 2 & $\begin{array}{l}\text { Post Receipt of } \\
\text { Customer Payment }\end{array}$ & $\mathrm{V}$ \\
\hline 3 & $\begin{array}{l}\text { View Customer } \\
\text { Balance }\end{array}$ & 3 \\
\hline \multicolumn{2}{|c|}{ Total } \\
\hline
\end{tabular}

Dari tabel 6 dapat disimpulkan aplikasi Odoo tidak memiliki kekurangan untuk proses customer payment karena telah cocok dengan best practices aplikasi SAP.

2. Analisis untuk Proses Pembelian Barang : Berikut ini disajikan analisis fitur untuk masing-masing tahapan pada proses pengadaan barang di aplikasi Odoo:

\section{Purchase Requisition}

Pada proses purchase requisition terdapat 18 fitur yang diamati. Berikut pemetaan kebutuhan fungsionalnya yang disajikan pada tabel 8 .

Tabel 8 Pemetaan Kebutuhan Fungsional Purchase Requisition

\begin{tabular}{|c|l|c|}
\hline No & \multicolumn{1}{|c|}{ Fitur } & Odoo \\
\hline 1 & Manage Purchase Requisition & $\mathrm{V}$ \\
\hline 2 & Create Purchase Requisition & $\mathrm{V}$ \\
\hline 3 & Update Purchase Requisition & $\mathrm{V}$ \\
\hline 4 & View Purchase Requisition & $\mathrm{V}$ \\
\hline 5 & Manage Vendor Master Data & $\mathrm{V}$ \\
\hline 6 & Create Vendor Master Data & $\mathrm{V}$ \\
\hline 7 & Update Vendor Master Data & $\mathrm{V}$ \\
\hline
\end{tabular}




\begin{tabular}{|c|c|c|}
\hline No & Fitur & Odoo \\
\hline 8 & View Vendor Master Data & V \\
\hline 9 & Manage Material Master Data & V \\
\hline 10 & $\begin{array}{l}\text { Create Material Master for } \\
\text { Trading Goods }\end{array}$ & $\mathrm{V}$ \\
\hline 11 & $\begin{array}{l}\text { Update Material Master for } \\
\text { Trading Goods }\end{array}$ & $\mathrm{V}$ \\
\hline 12 & View Material Master Data & V \\
\hline 13 & Manage RFQ & V \\
\hline 14 & Create $R F Q$ & $\mathrm{~V}$ \\
\hline 15 & Create RFQ without Reference & $\mathrm{V}$ \\
\hline 16 & $\begin{array}{l}\text { Create RFQ with Reference to } \\
\text { Preq }\end{array}$ & $\mathrm{X}$ \\
\hline 17 & Update $R F Q$ & $\mathrm{~V}$ \\
\hline 18 & View $R F Q$ & $\mathrm{~V}$ \\
\hline & Total & 17 \\
\hline
\end{tabular}

Dari tabel 8 dapat disimpulkan aplikasi Odoo dapat melakukan proses purchase requisition dengan sangat baik.

\section{Maintain Quotations from Vendors}

Pada proses maintain quotations from vendors terdapat 4 fitur yang diamati. Berikut pemetaan kebutuhan fungsionalnya yang disajikan pada tabel 9 .

Tabel 9 Pemetaan Kebutuhan Fungsional Maintain Quotation From Vendors

\begin{tabular}{|c|l|c|}
\hline No & \multicolumn{1}{|c|}{ Fitur } & Odoo \\
\hline 1 & $\begin{array}{l}\text { Maintain Quotation from } \\
\text { Vendors }\end{array}$ & $\mathrm{V}$ \\
\hline 2 & View Condition & $\mathrm{X}$ \\
\hline 3 & View Price Comparison & $\mathrm{V}$ \\
\hline 4 & Reject Quotation & $\mathrm{V}$ \\
\hline \multicolumn{2}{|c|}{ Total } & 3 \\
\hline
\end{tabular}

Dari tabel 9 dapat disimpulkan bahwa aplikasi Odoo memiliki fitur maintain quotation from vendors yang cukup lengkap.

\section{Purchase Order}

Pada proses purchase order terdapat 9 fitur yang diamati. Berikut pemetaan kebutuhan fungsionalnya yang disajikan pada tabel 10 .

Tabel 10 Pemetaan Kebutuhan Fungsional Purchase Order

\begin{tabular}{|c|l|c|}
\hline No & \multicolumn{1}{|c|}{ Fitur } & Odoo \\
\hline 1 & Manage PO & $\mathrm{V}$ \\
\hline 2 & Create PO & $\mathrm{V}$ \\
\hline 3 & $\begin{array}{l}\text { Create PO with Reference to } \\
\text { RFQ }\end{array}$ & $\mathrm{V}$ \\
\hline 4 & $\begin{array}{l}\text { Create PO with Reference To } \\
\text { Preq }\end{array}$ & $\mathrm{X}$ \\
\hline 5 & Create PO with Reference to & $\mathrm{X}$ \\
\hline
\end{tabular}

\begin{tabular}{|c|l|c|}
\hline No & \multicolumn{1}{|c|}{ Fitur } & Odoo \\
\hline & Previous PO & \\
\hline 6 & Create PO without Reference & $\mathrm{X}$ \\
\hline 7 & Update PO & $\mathrm{V}$ \\
\hline 8 & View PO & $\mathrm{V}$ \\
\hline 9 & View PO History & $\mathrm{V}$ \\
\hline \multicolumn{2}{|c|}{ Total } & 6 \\
\hline
\end{tabular}

Dari tabel 10 dapat disimpulkan bahwa aplikasi Odoo memiliki fitur purchase order yang cukup lengkap. Fitur-fitur utama yang seharusnya ada untuk tahapan purchase order dimiliki oleh aplikasi Odoo.

\section{Invoice Receipt}

Pada proses invoice receipt terdapat 6 fitur yang diamati. Berikut pemetaan kebutuhan fungsionalnya yang disajikan pada tabel 11.

\begin{tabular}{|c|l|c|}
\multicolumn{3}{|c|}{ Tabel 11 Pemetaan Kebutuhan Fungsional Invoice Receipt } \\
\hline No & \multicolumn{1}{|c|}{ Fitur } & Odoo \\
\hline 1 & Manage Invoice Receipt & $\mathrm{V}$ \\
\hline 2 & Create Invoice Receipt & $\mathrm{V}$ \\
\hline 3 & $\begin{array}{l}\text { Create Invoice with } \\
\text { Reference to Goods Receipt }\end{array}$ & $\mathrm{V}$ \\
\hline 4 & $\begin{array}{l}\text { Create Invoice with } \\
\text { Reference to PO }\end{array}$ & $\mathrm{V}$ \\
\hline 5 & Update Invoice Receipt & $\mathrm{V}$ \\
\hline 6 & View Invoice Receit & $\mathrm{V}$ \\
\hline \multicolumn{2}{|c|}{ Total } & 6 \\
\hline
\end{tabular}

Dari tabel 11 dapat disimpulkan bahwa aplikasi Odoo memiliki fitur invoice receipt yang lengkap.

\section{Payment to Vendor}

Pada proses payment to vendor terdapat 4 fitur yang diamati. Berikut pemetaan kebutuhan fungsionalnya yang disajikan pada tabel 12 .

Tabel 12 Pemetaan Kebutuhan Fungsional dari Payment to Vendor

\begin{tabular}{|c|l|c|}
\hline No & \multicolumn{1}{|c|}{ Fitur } & Odoo \\
\hline 1 & $\begin{array}{l}\text { Manage Fiancial } \\
\text { Accounting }\end{array}$ & $\mathrm{V}$ \\
\hline 2 & Post Payment to Vendor & $\mathrm{V}$ \\
\hline 3 & View Vendor Balance & $\mathrm{X}$ \\
\hline 4 & View G/L Account Balance & $\mathrm{V}$ \\
\hline \multicolumn{2}{|c|}{ Total } & 3 \\
\hline
\end{tabular}

Dari tabel di atas dapat disimpulkan bahwa aplikasi Odoo memiliki fitur payment to vendor yang lengkap dan dapat diandalkan.

\section{B. Hasil Analisis}

Berdasarkan proses analisis yang telah dilakukan, maka dipilih satu OSS ERP yang akan diterapkan di perusahaan. Oleh karena itu, penulis memilih aplikasi Odoo untuk diterapkan di Toko Emi Grosir dan Eceran dengan alasan sebagai berikut: 
1. Berdasarkan proses pre-sales activity, proses shipping, dan customer invoice diantara tiga aplikasi OSS ERP yang dibandingkan maka aplikasi Odoo merupakan yang paling efisien.

2. Aplikasi Odoo dapat mengelola proses bisnis sales order processing dengan baik dengan ditunjang fitur-fitur yang lengkap, Odoo hanya tidak memiliki fitur view document flow, fitur yang sebenarnya hanya bersifat opsional.

3. Untuk pengelolaan manage inventory dan customer payment, aplikasi Odoo memiliki fitur yang sama dengan aplikasi best practices SAP.

4. Pada proses purchase requisition aplikasi Odoo cukup kompleks sehingga dapat menangani proses tersebut dengan baik.

5. Untuk proses maintain quotations from vendors aplikasi Odoo memiliki fitur yang cukup lengkap.

6. Pada proses purchase order dan payment to vendor aplikasi Odoo dapat melakukannya dengan baik, fiturfitur yang bersifat opsional tidaklah dimiliki.

7. Untuk proses invoice receipt aplikasi Odoo sangatlah mumpuni karena memiliki fitur yang sama dengan aplikasi best practices SAP.

\section{PENERAPAN DAN PENGUJIAN}

\section{A. Infrastruktur}

Adapun infrastruktur yang digunakan dalam proses penerapan yaitu sebuah laptop atau komputer, dimana aplikasi Odoo dijalankan pada localhost.

1. Spesifikasi Perangkat Keras : Adapun spesifikasi perangkat keras komputer yang digunakan dalam penerapan OSS ERP aplikasi Odoo adalah sebagai berikut:
- Komputer
: Laptop Toshiba Satellite L645
- Processor
: Intel(R) core(TM) i3 CPU/2.40
$\mathrm{GHz}$
- RAM : $2 \mathrm{~GB}$
- Harddisk : $500 \mathrm{~GB}$
- Modem/LAN : Movimax
- OSS ERP yang Digunakan : Odoo

2. Spesifikasi Perangkat Lunak : Adapun spesifikasi perangkat lunak komputer yang digunakan dalam penerapan aplikasi Odoo adalah sebagai berikut:

- Sistem Operasi : Windows 8.1 Pro 32-bit

- Database : PostgreSQL

- Web browser : Google Chrome

\section{B. Instalasi Perangkat Lunak OSS ERP Odoo}

Sebelum melakukan penerapan, terlebih dahulu dilakukan instalasi aplikasi Odoo agar dapat berjalan sebagaimana mestinya. Adapun aplikasi Odoo dapat di unduh dari situs https://www.odoo.com/ pilih menu download, isikan biodata lalu pilih Odoo dengan platform windows dan version 8 seperti gambar 9 .

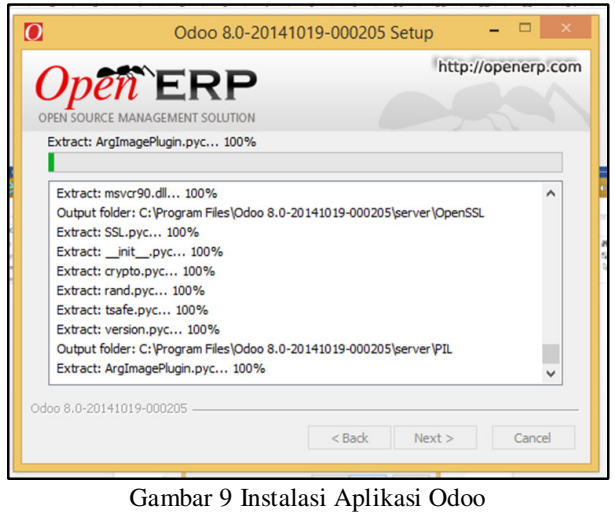

Setelah proses instalasi selesai berikut tampilan seperti gambar 10.

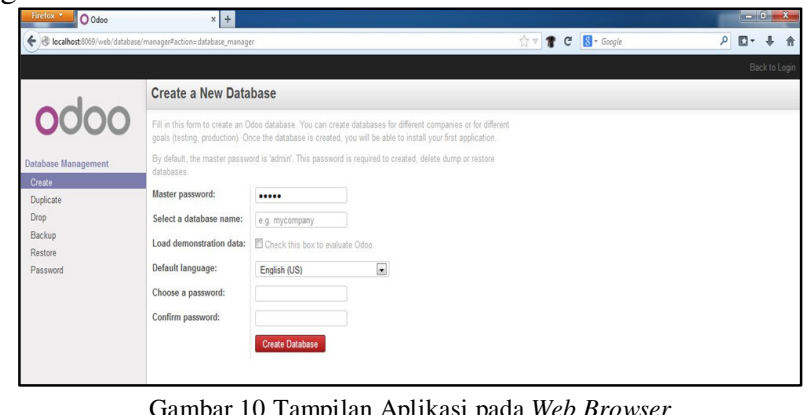

\section{Persiapan Penerapan Aplikasi}

Setelah proses penyiapan infrastruktur dan instalasi perangkat yang dibutuhkan selesai, tahap selanjutnya adalah melakukan penerapan aplikasi. Untuk perusahaan seperti Toko Emi Grosir dan Eceran yang tergolong perusahaan dagang, maka ada beberapa pengaturan dasar sebelum proses penerapan aplikasi dilakukan yaitu:
a. Membuat database
b. Instalasi modul yang digunakan
c. Menentukan akun dan tipe akun yang digunakan
d. Input data pemasok
e. Input data pelanggan
f. Input data beberapa produk
g. Pengaturan gudang

Sementara itu, agar dapat melakukan transaksi, setidaknya diperlukan satu pemasok, satu pelanggan, satu produk, sebuah gudang, dan chart of accounts.

\section{Penerapan Aplikasi ERP Odoo}

Pada tahapan ini dilakukan penerapan untuk masingmasing proses bisnis di Toko Emi Grosir dan Eceran yaitu pembelian barang, pengelolaan gudang, dan penjualan barang.

1. Pembelian Barang Kepada Pemasok: Sebagaimana proses yang sedang berjalan pada perusahaan dan proses bisnis aplikasi, maka langkah-langkah dalam pembelian barang adalah sebagai berikut: 


\section{Request for Quotation}

Quotation berisi negoisasi atau diskusi yang dilakukan dengan pemasok untuk menentukan barang yang akan dipesan. Apabila telah terjadi kesepakatan terhadap barang yang akan dipesan maka quotation berubah menjadi purchase order. Pada aplikasi Odoo dapat dilakukan request for quotation terlebih dahulu, atau dapat juga langsung melakukan purchase order. Untuk melakukan request for quotation gunakan menu Purchases lalu pilih purchase for quotation.

2. Pesanan pembelian (Purchase Order)

Setelah tombol confirm order diklik, maka akan muncul tampilan gambar 11 sebagai berikut:

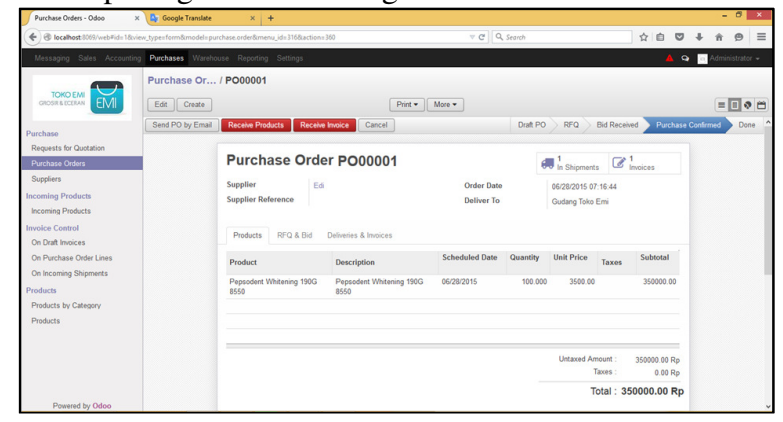

Gambar 11 Form purchase order

Dari gambar di atas purchase order telah dilakukan, yang artinya pemesanan barang telah disepakati dengan pemasok.

3. Penerimaan barang (Receiving Goods)

Setelah pesanan dikonfirmasi, pihak perusahaan akan menunggu pengiriman barang dari pemasok.

Jika pengiriman barang sudah dilakukan, untuk mengecek barang dapat dilihat di gudang, dengan mengklik menu warehouse, pilih inventory control lalu pilih menu current inventory control.

4. Invoice Control

Ketika telah menerima invoice dari supplier, maka langkah selanjutnya adalah pergi ke menu accounting pilih supplier lalu klik supplier invoices. Maka akan tampak invoices yang masih berupa draft, klik invoices yang masih berupa draft tersebut.

Barang yang telah diterima dapat dibandingkan dengan invoices. Jika sudah sesuai maka tinggal divalidasi dengan mengklik tombol validasi. Jika belum maka dapat dilakukan pengubahan.

5. Pembayaran Kepada Supplier

Jika draft invoices telah di open maka langkah selanjutnya adalah klik pay pada invoices.

Jika ingin melakukan cetak invoice pilih menu print, berikut tampilan cetak invoice seperti gambar 12 .

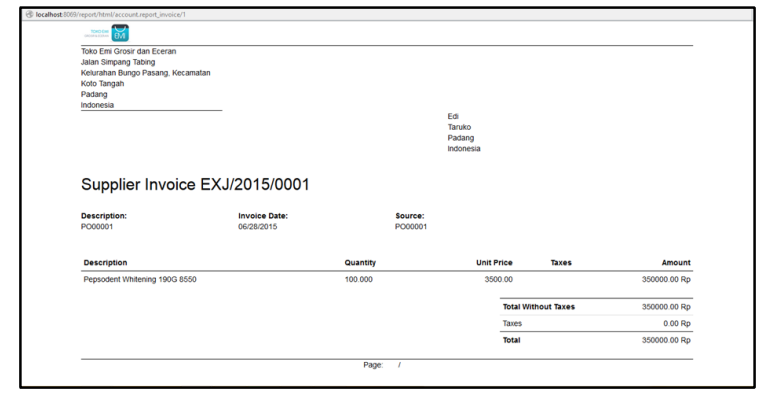

Gambar 12 Tampilan cetak invoices

2. Penjualan Barang Kepada Pelanggan : Adapun langkahlangkah penjualan barang kepada pelanggan adalah sebagai berikut:

1. Quotation

Sebelum dilakukan sales order, terlebih dahulu dilakukan quotation. Untuk dapat membuat quotation maka pilih menu sales, ambil quotation.

2. Sales Order

Setelah dilakukan confirm sale pada quotation maka akan menjadi sales order, berikut tampilan dari sales order pada gambar 13.

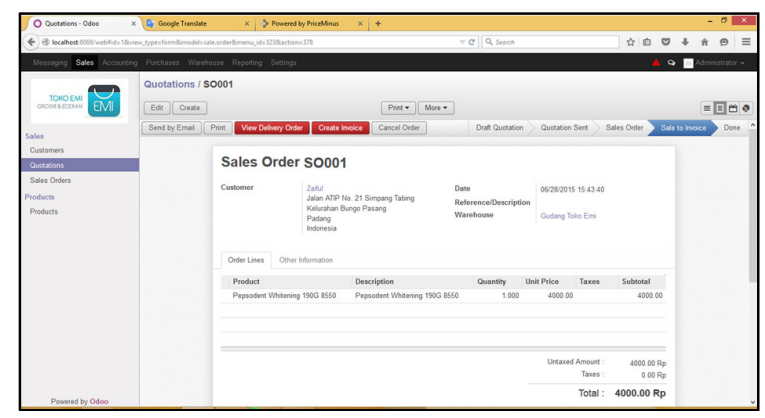

Gambar 13 Form sales order

3. Mengirim Barang Kepada Pelanggan

Setelah proses sales order dilakukan, maka kemudian dilakukan pengiriman barang kepada pelanggan. Klik view delivery order untuk mengetahui teknis pengiriman barang kepada pelanggan.

4. Faktur Barang

Untuk dapat membuat invoice maka pilih create invoice, dengan serangkaian tahapan maka muncul invoices sebagai berikut: lalu akan muncul tampilan seperti gambar 14.

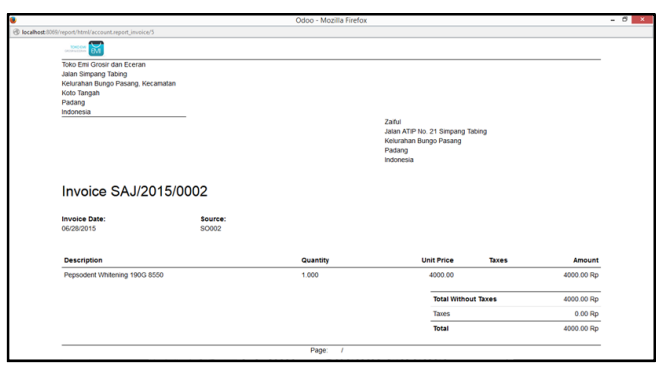

Gambar 14 Hasil cetak invoice 
5. Pembayaran oleh Pelanggan

Setelah dilakukan cetak invoice, lalu klik tombol register payment.

3. Pengelolaan Gudang : Untuk dapat melakukan pengelolaan gudang baik, maka tahapannya adalah sebagai berikut:

1. Pada menu warehouse pilih menu inventory control lalu klik fitur current inventory valuation, maka tampilannya seperti gambar 15 .

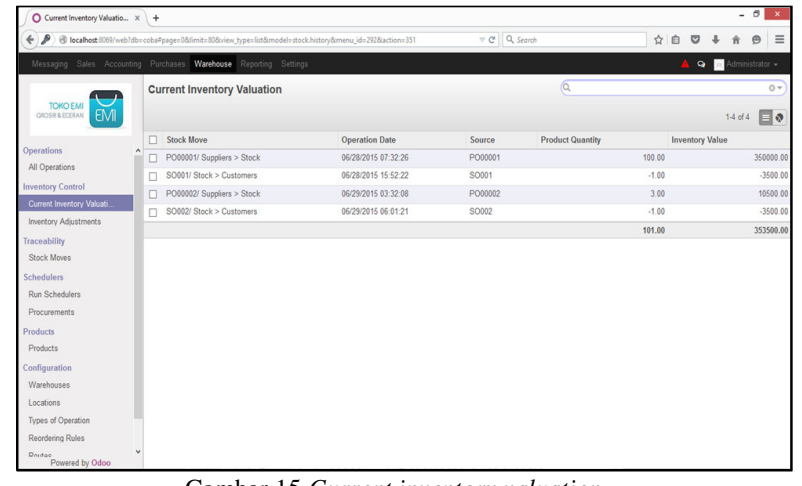

Gambar 15 Current inventory valuation

Dari gambar 15 dapat dilihat arus perpindahan barang yang terjadi pada sebuah perusahaan.

2. Sementara itu untuk melacak arus perpindahan barang secara lebih detil dapat dilakukan dengan cara pilih menu traceability dan lalu klik fitur stock moves, maka akan tampil gambar 16.

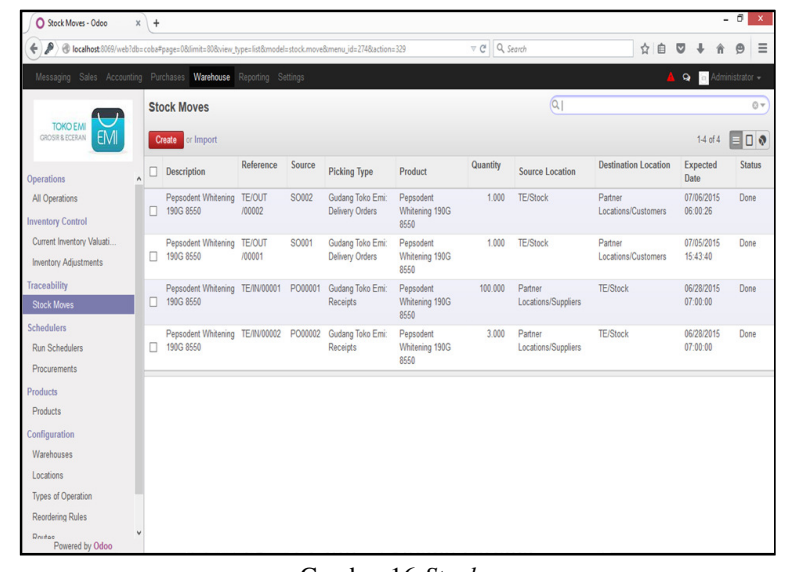

Gambar 16 Stock moves

\section{E. Pengujian}

Tahapan pengujian merupakan salah satu tahapan terpenting pada penelitian ini. Pada tahapan ini hasil penerapan aplikasi yang telah dilakukan akan dibandingkan dengan proses manual yang dilakukan perusahaan.

1. Pengujian Pembelian Barang : Pada tahapan ini proses pembelian barang yang dilakukan oleh perusahaan, memeroleh faktur seperti yang terlihat pada gambar 16 .

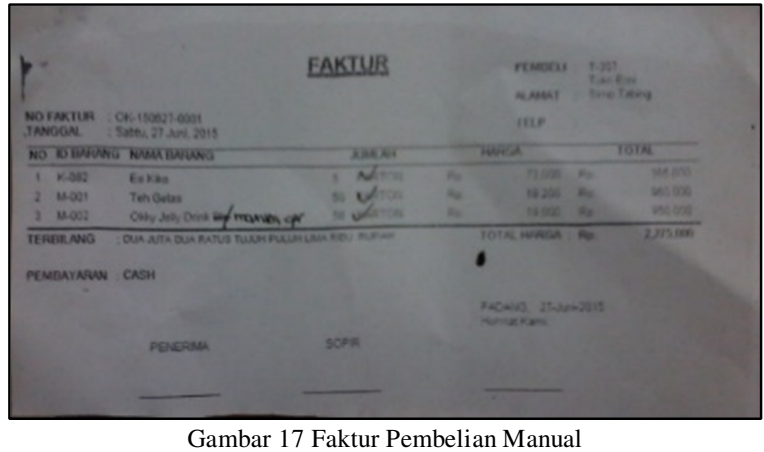

Sementara itu proses penerapan yang telah dilakukan menghasilkan faktur pembelian barang lebih baik. Seperti yang terlihat pada gambar 18 .

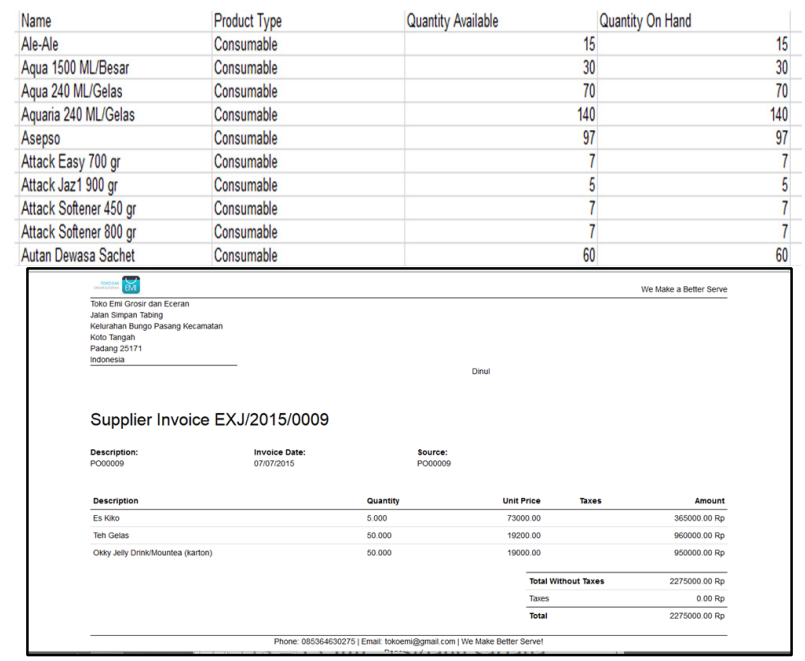

Gambar 18 Pencatatan Pembelian Barang

2. Pengujian Laporan Persediaan Barang : Pada Toko Emi Grosir dan Eceran pencatatan persediaan tidak dilakukan dengan baik. Dengan penerapan aplikasi Odoo yang telah dilakukan pencatatan persediaan barang menjadi lebih baik dan efisien.

3. Pengujian Penjualan Barang : Pada Toko Emi Grosir dan Eceran aktivitas penjualan tidak memiliki pencatatan yang jelas. Adapun bentuk faktur penjualan yang dihasilkan aplikasi Odoo adalah seperti gambar 19.

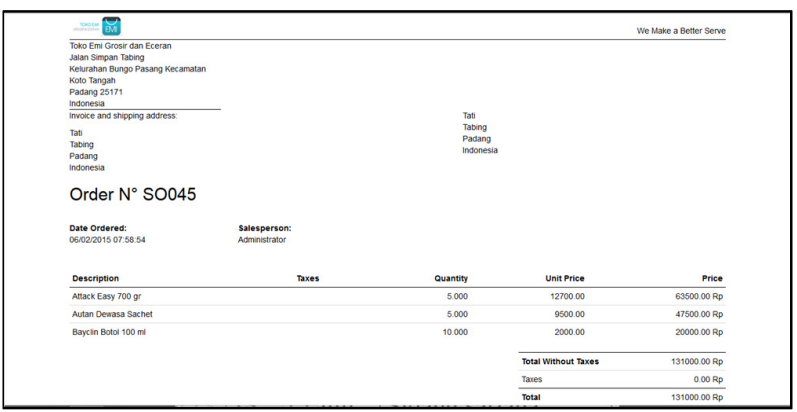

Gambar 19 Data Pesanan Penjualan 


\section{F. Laporan yang Dihasilkan}

Berikut ini disajikan otomatisasi laporan yang dapat dihasilkan dari aplikasi Odoo, yaitu laporan keuangan perusahaan, laporan pembelian, laporan persediaan barang, dan laporan penjualan barang.

\section{Laporan Profit and Loss}

Berikut laporan Profit and Loss yang dihasilkan aplikasi Odoo untuk Toko Emi Grosir dan Eceran seperti terlihat pada gambar 20 .

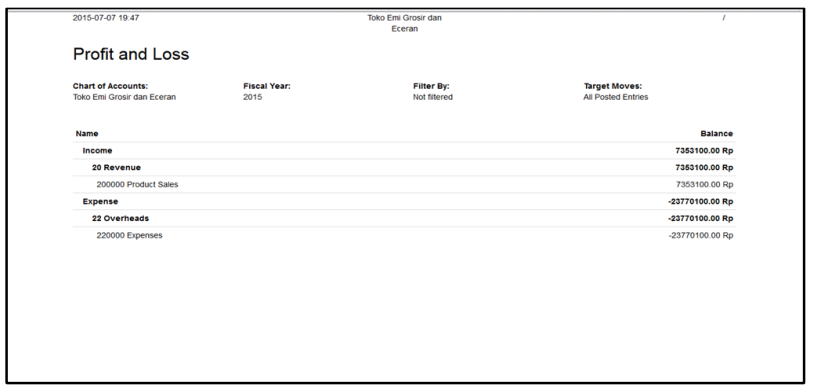

Gambar 20 Laporan Profit and Loss

\section{Laporan Balance Sheet}

Berikut laporan Balance Sheet yang dihasilkan aplikasi Odoo untuk Toko Emi Grosir dan Eceran seperti terlihat pada gambar 21 .

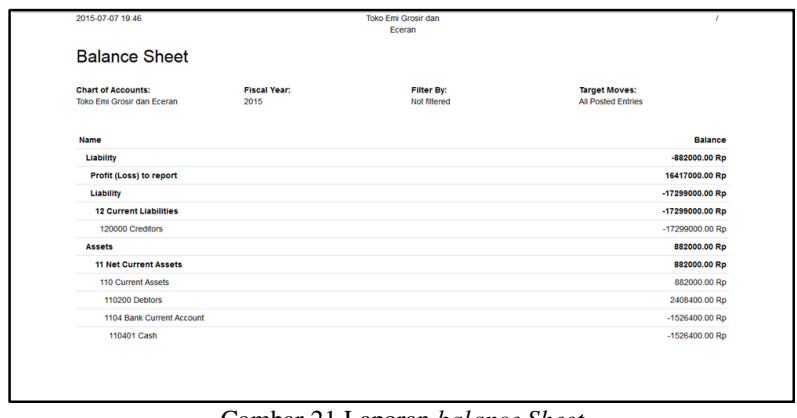

Gambar 21 Laporan balance Sheet

3. Laporan pembelian

Berikut laporan pembelian dari Toko Emi Grosir dan Eceran seperti yang terlihat pada gambar 22.

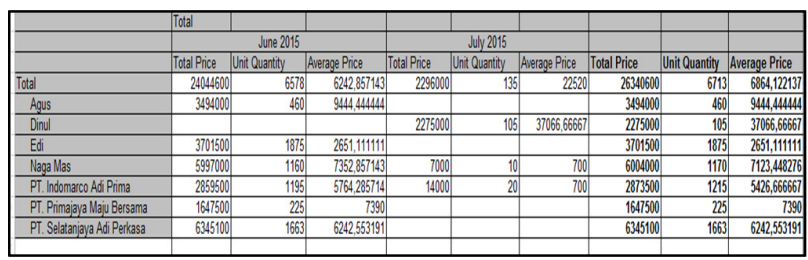

Gambar 22 Laporan pembelian

\section{Laporan Persediaan Barang}

Adapun laporan persediaan barang dapat dilihat pada gambar 19.

5. Laporan Penjualan

Adapun laporan penjualan barang dapat dilihat pada gambar 23.

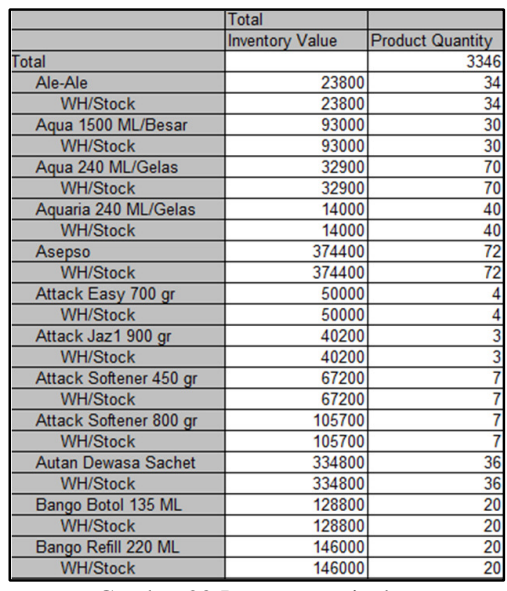

Gambar 23 Laporan penjualan

\section{G. Evaluasi Pengujian Aplikasi}

Berdasarkan pengujian aplikasi yang telah dilakukan, maka ada beberapa hal yang dapat dievaluasi antara lain:

1. Pengujian yang dilakukan telah menjawab permasalahan yang ada pada perusahaan, seperti penyediaan informasi ketersediaan barang di gudang dengan cepat dan akurat.

2. Pengujian tersebut telah dapat menghasilkan laporanlaporan dengan mudah dan efisien yang sesuai dengan laporan-laporan yang dibuat secara manual.

\section{PENUTUP}

\section{A. Kesimpulan}

Berdasarkan penerapan dan pengujian aplikasi yang dimulai dari tahap identifikasi permasalahan, analisis proses bisnis perusahaan, analisis pemilihan perangkat lunak yang digunakan, serta proses penerapan dan pengujian, maka dapat disimpulkan bahwa penerapan Enterprise Resource Planning (ERP) untuk sistem informasi pembelian, persediaan, dan penjualan barang pada Toko Emi Grosir dan Eceran berhasil diterapkan dengan rincian sebagai berikut:

1. Proses bisnis pembelian barang, persedian, dan penjualan barang pada Toko Emi Grosir dan Eceran yang telah terkomputerisasi, artinya sudah mampu mengatasi permasalahan yang muncul antara lain lambatnya informasi ketersediaan barang di gudang.

2. Hasil pengujian penerapan aplikasi membuktikan bahwa proses yang terjadi di Toko Emi Grosir dan Eceran menjadi lebih cepat dibandingkan dengan proses manual yang dilakukan sebelumnya.

3. Dengan proses yang sudah terkomputerisasi itu, Toko Emi Grosir dan Eceran dapat menghasilkan laporan pembelian, persediaan, dan penjualan barang serta laporan keuangan secara real time sehingga tidak banyak menghabiskan biaya dan waktu untuk dapat membuat laporan-laporan tersebut.

\section{B. Saran}

Berdasarkan hasil penelitian, maka disarankan pada penelitian selanjutnya dilakukan pengembangan sistem yang lebih terintegrasi tidak hanya untuk sistem informasi pembelian, persediaan, dan penjualan barang namun juga 
mencakup pengembangan sistem informasi lainnya antara lain human resources management dan customer relationship management serta modul-modul penunjang seperti point of sales dan e-commerce.

\section{REFERENSI}

[1] Nurcahyo, Yusuf Eko., Purnomo Budi Santoso., dan Rudy Soenoko. (2012). Penerapan Enterprise Resource Planning (ERP) Adempiere pada Perusahaan PT Global Agrotek Nusantara (GAN). BISTEK Jurnal Bisnis dan Teknologi. 20 (1), 76-86

[2] Yogeswara, W.K., Wisnubhadra, I., dan Mudjihartono P. (2013). Analisis dan Rancang Bangun Sistem Informasi Hotel Terintegrasi yang Selaras dengan Rencana Strategis Teknologi Informasi. Proceeding Seminar Nasional Teknologi Informasi dan Komunikasi.

[3] Hendarti, Henny., Yuliana Lisanti., dan Yuna Wijaya. (2011). Studi Kelayakan Rencana Penerapan Software ERP (Enterprise Resource Planning). Prosiding Seminar Nasional Manajemen Teknologi XIV.

[4] N. Serrano \& JM Serriegi, (2006), "Open Source Software ERPs : A New Alternative for an Old New,"IEEE Computer Society, Vol 23, pp. 94-97

[5] Handayani, Putu Wuri dan Ultary Hariyaty. (2011). Analisis Fungsionalitas Open Source Software ERP untuk Pengembangan Modul Pembelajaran ERP. 7 (2), 118-125.

[6] Motiwalla, Luvai. V dan Jeff Thompson. (2009). Enterprise Systems for Management. Pearson Education, Inc, New Jersey, USA

[7] Hasibuan, Muhammad Azni. (2015). Seleksi Produk ERP Open Source Menggunakan AHP : Studi Kasus UKM Pengembangan Perangkat Lunak. Jurnal Rekayasa Sistem dan Industri.2 (2), Hal 1-6

[8] OpenERP. (2011). United State. Retrieved March 12, 2011, from https://www.openerp.com

[9] Assauri, Sofjan. (2008). Manajemen Produksi dan Operasi. (Ed. Revisi). Penerbit Fakultas Ekonomi Universitas Indonesia, Jakarta, Indonesia

[10] Ristono, Agus. (2009). Manajemen Persediaan. (Ed. 1). Graha Ilmu, Yogyakarta, Indonesia

[11] Mulyadi. (2007). Sistem Perencanaan dan Pengendalian Manajemen (Ed.3). Salemba Empat, Jakarta, Indonesia 